\title{
Failed Government, Youths Unemployment and the Challenges of Insecurity in Nigeria: The Need for Entrepreneurial Skills Development and Citizens Investment in Small Scale Businesses
}

\section{Oladimeji Sogo Osewa}

Nigerian Defence Academy, Faculty of Arts and Social Sciences, Department of Political Science and Defence Studies, Nigeria

OrcidID: https://orcid.org/0000000337494879; E-Mail: osewa.oladimeji@gmail.com

Area of the Paper: Business Management.

Type of the Paper: Research Paper.

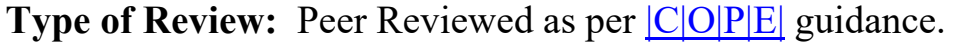

Indexed In: OpenAIRE.

DOI: http://doi.org/10.5281/zenodo.3941068.

Google Scholar Citation: IJCSBE.

\section{How to Cite this Paper:}

Oladimeji Sogo Osewa. (2020). Failed Government, Youths Unemployment and the Challenges of Insecurity in Nigeria: The Need for Entrepreneurial Skills Development and Citizens Investment in Small Scale Businesses. International Journal of Case Studies in Business, IT, and Education (IJCSBE), 4(1), 188-206. DOI: http://doi.org/10.5281/zenodo.3941068.

International Journal of Case Studies in Business, IT and Education (IJCSBE) A Refereed International Journal of Srinivas University, India.

(C) With Author.

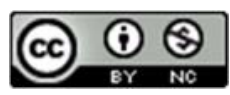

This work is licensed under a Creative Commons Attribution Non-Commercial 4.0 International License subject to proper citation to the publication source of the work.

Disclaimer: The scholarly papers as reviewed and published by the Srinivas Publications (S.P.), India are the views and opinions of their respective authors and are not the views or opinions of the S.P. The S.P. disclaims of any harm or loss caused due to the published content to any party. 


\title{
Failed Government, Youths Unemployment and the Challenges of Insecurity in Nigeria: The Need for Entrepreneurial Skills Development and Citizens Investment in Small Scale Businesses
}

\author{
Oladimeji Sogo Osewa \\ Nigerian Defence Academy, Faculty of Arts and Social Sciences, Department of Political \\ Science and Defence Studies, Nigeria \\ OrcidID: https://orcid.org/0000000337494879; E-Mail: osewa.oladimeji@gmail.com
}

\begin{abstract}
Nigerian state has been bedeviled by poverty and unemployment, one that has emerged due to the failure of Nigerian government to perform her constitutional functions of providing her citizenry with the basic needs of lives, especially employment through which food could be put on the table of the masses. Unemployment ravaging the citizens of Nigeria has become devastating, as it has grown to its climax that in the time past, senator Dino Melaiye, a senator from Kogi west senatorial district once submitted on the flow of the house of senate that the high rate of youth unemployment in Nigeria is sending a signal that Nigerian state is sitting on a time bomb which could explode at any point in time if the menace is not quickly addressed. The Minister of labour and employment Chris Ngige once posits that the unemployment rate may increase from $23.1 \%$ to $33.5 \%$ by this year 2020 . The need to addressing this issue is the reason why this paper examines the causes of unemployment in Nigeria, and analyze the need for the development of entrepreneurial skills, and the establishment of small-scale businesses as the panacea to the menace of unemployment in Nigeria. The paper adopted the diversification theory in explaining the need for Nigerian graduates to diversify from the attitude of searching for white collar jobs only to the idea of setting up and investing in small scale businesses. This paper examines the impact of unemployment on Nigeria and suggests the establishment of small-scale businesses and entrepreneurial skills development as a way to go in tackling the menace of unemployment in Nigeria. The paper adopted the secondary method of data collection as valuable information's and data are retrieved from the readymade works of scholars and authors, while other information's are gathered through the common-sense views and knowledge of the writer.
\end{abstract}

Keywords: Unemployment, Governmental Failure, Insecurity, Small Scale Businesses, Entrepreneurial Skills.

\section{INTRODUCTION :}

The Nigerian State has long been entangled by poverty and unemployment. The crawling economy and the staggering development is another subject of discussion. Section 14 (2b) of the 1999 constitution of the federal republic of Nigeria analyses that, the primary purpose of government is to protect lives and properties of the citizenry, and guarantee welfare of all citizens in Nigeria. However, these stipulations of the constitution have been violated as Nigerian government have failed in her constitutional responsibility of guaranteeing altruism, that is, concern for the interest and welfare of others in the state, as selfishness and self-centeredness, corruption have now signified in the character of Nigerian political leaders. Nevertheless, if there is any one concept that has been held responsible for Nigerian's ever dwindling fortune in the midst of abundant natural endowment, it is the word corruption (Nwadike, 2013) [1]. However, the attributes of a good leader are to be honest at all time, particularly on issues of public interest and the decision pertaining to it (Eke, 2001) [2]. Citizens of 
Nigeria has been denied of their basic needs of lives especially employment which has called for the engagement of citizens in series of social vices that are now seen by the citizens as an alternative route to survival in Nigeria. According to the Bureau of statistics, they state that $38 \%$ of the population that falls within the employable age is unemployed and $65 \%$ of Nigerian youths face unemployment as at September 2016 (Olawale, 2017) [3].

Any government, military or civilian has an obligation to the people living in that geo-political territory to ensure adequate economic, security and political stability (Eke, 2001) [2]. Most political violence and social unrest witnessed in the world have their background to the inability of government to fulfill or improve upon the economic needs of the people (Eke, 2001) [2]. To be factual, most of the armed crime experienced in Nigeria today emerged as a result of the failure of Nigerian government to constitutionally and economically protect her citizenry (Osewa, 2019) [4]. The effect of unemployment in Nigeria have been so devastating that quite a number of Nigerians especially the youths have been living in poverty and penury. Over 55.4 percent youths people aged 18 to 35 are unable to find suitable work to earn a living (Isayinka, 2019) [5]. Nearly a quarter of the entire Nigerian population is out of work and over 20 per cent is underemployed (Isayinka, 2019) [5]. The necessity to survive has now made citizens engaged in armed and unarmed crimes such as yahoo-yahoo, political thugs and area boys activities, armed robbery, kidnapping, drug trafficking and terrorism which had become problematic to Nigerian state. Nigerians are now living under a state of insecurity where lives is "solitary poor, nasty, brutish and short" a society where the freedom from fear and freedom from want is lacking, while the insecure nature of the state has reduced the inflow of foreign investors as some foreign investment already in Nigeria like Mobil and Unilever have now relocated their head offices to other countries like Ghana. This has in turn deepened the unemployment and poverty rate while affecting the economy of Nigeria in the long run.

Nevertheless, the rate of unemployment in Nigeria is alarming that a quicker solution is needed as waiting for solution from the government is an illusion, expectation that will never come to reality. Diverting into entrepreneurial skills development and small scale businesses would go a long way in addressing the menace of high rate of unemployment in Nigeria. Adejimola (2009) [6] submits that the" introduction of entrepreneurship education as a compulsory course in Nigerian universities or higher institutions is seen as a measure to address the problem of graduate unemployment and strategically repositioned the economy for leadership position in Africa'. Indeed the development of small scale businesses and the engagement of citizens in entrepreneurship activities are the right step and right way to go. There seems to be general consensus that the major contribution of small scale business and the employment that it offered to a large proportion of the population makes it very important www.articlesng.com>roles-small-scale-industries. Establishment of small scale business makes possible the realization of government policy thereby closing the gap between the rural and urban centers (op cit).

\section{THEORETICAL FRAMEWORK :}

\subsection{DIVERSIFICATION OR MODERN PORTFOLIO THEORY (MPT) (1952)}

This theory was developed by Harry Markowitz, and was published under the title "portfolio selection" in the journal of finance in 1952. As analyses by Ben Mcclure (2020) [7] he submits that modern portfolio theory is one of the most important and influential economic theory dealing with finance and investment. He submits that the theory is based on Markowitz hypothesis that, it is possible for investors to design an optimal portfolio to maximize returns by taking on a quantifiable amount of risk. Essentially, investors can reduce risk through diversification using a quantitative method. He explained that modern portfolio theory says that it is not enough to look at the expected risk and returns of one particular stock. Mcclure posits that by investing in more than one stock, an investor can reap the benefits of diversification-chief among them, a reduction in the riskiness of the portfolio. MPT quantifies the benefits of diversification, or not putting all of your eggs in one basket.

This theory as applied in these works, as it is used to explain the reason why unemployed Nigerian graduates should diversify from the act of awaiting and searching for white collar jobs only, to investing in small scale businesses or entrepreneurial activities. The theory above explains that, it is possible for investors to design an optimal portfolio to maximize returns by taking on a quantifiable amount of risk. Nevertheless, it is also possible for Nigerian unemployed graduates to multiply and 
design another way through which they could be engaged in order to come out of the unemployment ravaging them (citizenry), as they quantify their risk of preparing for not only one option, but more options. The theory advices one not to look at the expected risk of, and returns of one particular stock. This implies that unemployed graduates of Nigeria should not rely on just one risk, and returns of searching for white collar jobs only, but by preparing for more options of engagement be it small scale business investment simultaneously with white collar jobs, so that Nigerian unemployed graduates can reap the benefit of diversification, as they have offset the risk of putting their eggs in one basket.

\section{CONCEPTUAL CLARIFICATION :}

\subsection{FAILED GOVERNMENT}

The failure of government to meet up with her constitutional responsibilities especially when it comes to creating employment opportunities has become a challenge in Nigeria. People tend to refer to governance in Nigeria as being bad governance. Governance as define by Espanol (2019)[8] he posits that governance is a structures and processes that are designed to ensure accountability, transparency, responsiveness, empowerment, rule of law, stability, equity, inclusiveness and broad base participation. These facts are lacking in Nigeria governance hence failed state. What are the views of scholars on the concept failed state.

Barma (2019) [9] submits that a failed state is a state that is unable to perform the two fundamental functions of the sovereign nation-state in the modern world system. It cannot project authority over its territory and peoples, and it cannot protect its national boundaries. The government capacity of a failed state is attenuated such that is unable to fulfill the administrative and organizational task required to control people and resources and can provide only minimal public services. Global policy forum (2013) [10] argued that a failed state is a state that can no longer perform basic functions such as education, security, employment, or governance, usually due to fractious violence or extreme poverty. Within this power vacuum, people fall victim to competing factions and crime. According to https://en.m.wikipedia.org $>$ wiki $>$ failed a failed state is a political body that has disintegrated to a point where basic conditions and responsibilities of a sovereign government no longer function properly. A state can also failed even if it is performing its functions properly. For a stable state, it is necessary for government to enjoy both effectiveness and legitimacy. Likewise, when a nation weakens and its standard of living declines, it introduces the possibility of total government collapse, as it will be unable to provide public service'”.

A failed state is a state with a very weak governmental structures, as most of the functions of government are lacking especially employment and education, one that can breeds poverty in the state thereby aiding the citizens to engaging themselves in armed and destructive crimes as a means of survival which in turn lead to insecurity and breaking down of internal and external sovereignty in the state. The un-doubtable fact is that our beloved nation Nigeria has not meet up with its expectations, as government has abysmally failed in their constitutional responsibility of protecting the people, and in turn forfeited the purpose for the creation of state as argued by the social contract theorist.

\subsection{UNEMPLOYMENT}

The word unemployment is a single word with different definitions depending on scholar's perceptions. However, Amadeo (2019) [11] submits in his work that unemployment as argued by the Bureau of labor statistics in the U-3 report as the people who do not have a job, have actively looked for work in the past four weeks and are currently available for work. Chappelow (2019) [12] submits that unemployment occurs when a person who is actively searching for employment is unable to find work. Unemployment is often used as a measure of the health of the economy. The most frequent measure of unemployment is the unemployment rate which is the number of unemployed people divided by the number of people in the labor force.

Pettinger (2019) [13] argued that unemployment is define as a situation where someone of working age is not able to get a job but would like to be in full time employment. As written in IMF economic essay they posit that ILO define unemployment as "those who are currently not working but are willing and able to work for pay, currently available to work, and have actively search for work". While they analyses unemployment by IMF as posit "under the labor force survey (LFS) methodology, unemployed persons are defined as those aged 15 years and over, who fulfill the following three conditions; did not have any work during reference week, had been actively seeking a job during the 
last four weeks or who found a job to start within a period of at most three months; was able to start to work in the next two weeks".

World Bank as analyzed in the IMF essay, "unemployment refers to the share of the labor force that is without work but available for, and seeking employment". Nevertheless, unemployment is a situation where citizens of a country are able, willing and ready to work haven acquired the necessary qualifications and possess the needed skills, but unable to secure jobs due to the deteriorating economic condition of the country and the corrupt attitudes of the leadership governing such country, hence bad governance. However, it is germane to note that, not all jobless citizens are unemployed. Some are unemployed just for the main time of going on a higher study or a period of looking for another job, while some are not willing to take up a less paid job or being underemployed. Nevertheless, a well politically structured state with a good government can allay the spirit of the menace of unemployment and vice-versa.

\subsection{SMALL SCALE BUSINESS}

As submit by Edmund and Seidel (2019) [14] a small scale enterprise is one marked by a limited number of employees and a limited flow of finances and materials. Tersoo (2019) [15] argued that small scale business is a business that does not require any major investment, does not require hundreds of thousands and millions of Nigeria or US dollars, and can be run by one or two people without the need to create a big company with more workers. A small scale business is a privately owned business with a small employee capacity. It ranges from operating a small shop like a bakery, saloon, and restaurant to online businesses and to professional firms like accounting or law firm https://www.pulse.ng>news $>$ small-scale. Nevertheless, small scale business is a small business set up, that requires no training or very little training and can be run by one, two or more persons, as most of such business can thrive in an environment with little social amenities.

\subsection{ENTREPRENEURSHIP}

The word entrepreneurship will certainly have different definition to different people, even though their idea may be connected in some areas. However, let us consider the perceptions of some scholars on the concept. Olufisayo (2010) [16] argued that entrepreneurship "is concerned with the identification of gaps and business opportunities in one's immediate environment and bringing together the necessary resources in an innovative way to fill these gaps, bearing the risk involves and in the process gaming personal rewards. It is the willingness, ability or capacity of an individual to seek out investment opportunities, to establish and run enterprises successfully'. Ferreira (2019) [17] posit that" entrepreneurship is the act of creating a business or businesses while building and scaling it to generate a profit'”.

The definition of entrepreneurship by Adam Smith as analyzed in https://onlinelibrary.wiley.com $>$ pdf $>$ sej. He submits that "entrepreneurship can be defined as the study of human actions that lead to changes in the division of labor". Nevertheless, entrepreneurship is really broad in meaning, to some people it is called small and medium scale business. It could be that skill acquired through skill acquisition program, one that is generally refers to as hand work. It is called ise owoo by the yoruba's. Nevertheless, it is the activities of learning and investing in what is learnt in order to make profit and achieve ones ends means having in mind risk bearing. Entrepreneurship is like investing in a particular business on profit making. It involves an art of creating new thing (innovation and invention) used in solving societal problem. Entrepreneurship could manifest in form of one-man business (Onemannism) or involving more than one person (partnership). Entrepreneurship development is important in a country in that it enhances the economy of a given country, while engaging citizens fully and can put food on individual citizens table. Entrepreneurship and small-scale business set up are interconnected as both implies the investment in small scale or medium scale business with risk of profit making and run by limited numbers of person.

\section{THE NEXUS BETWEEN FAILED STATE, UNEPLOYMENT AND SMALL SCALE ENTERPRISES OR ENTREPRENEURSHIP :}

A failed state is a state that is unable to protect her citizenry in terms of lives and properties, and unable to provide her citizens with the basic needs of lives (freedom from fear and want), thereby leading to 
the brake down of the state internal sovereignty as the citizens will no longer want to respect and support the government. It is a state that cannot, or does not have the power to strongly held on, protect her external sovereignty and has loose its freedom and respect internationally. However, a state who has failed in her constitutional responsibility of providing holistic security to her citizens especially employment will lose its respect as high rate of unemployment will ravage the state. The unemployed and badly conscientize citizens will see criminal act as the only means of survival when they are ravaged by poverty. Nevertheless, in a civilized society with educated and morally sound citizens, development of small scale business and entrepreneurship skill development will be seen as the workable way out of the poverty as opposed engaging in crime. However, let us examine the causes of unemployment in Nigeria.

\section{WHAT ARE THE CAUSES OF UNEMPLOYMENT IN NIGERIA?}

Many factors accounted for the causes of unemployment in Nigeria. These factors as argued by this paper are bad governance, crawling economy, insecurity, over reliance on white collar jobs and corruption. Each of these factors is addressed below.

(1) Bad governance- unemployment in Nigeria didn't just emerged naturally, it is not a natural occurrence, and it is caused by certain factors. Bad governance is seen as one of the major factors that causes unemployment in Nigeria. The inability or the failure of Nigerian government to take up their governmental responsibilities, that mostly has to do with the provision of basic needs of lives, and that will guarantee citizens welfare and allay the spirit of fear of actualizing citizen's needs, thereby guaranteeing Nigerian citizens freedom from want. One of the most important needs of the citizens is good job (employment) to put food on the table of every family and to avert poverty. One of the causes of unemployment in Nigeria is poor leadership and high levels of corruption in Nigeria (Olawale, 2017) [3]. The failure of the government to perform their constitutional duties has resulted in high rate of unemployment (up cit). The corrupt attitude of Nigerian leaders which has to do with self-centeredness, and has led to the embezzlement of public funds that would have been used for public welfare. The high rate of corruption in Nigeria among politicians has resulted in mismanagement of the funds and resources that is supposed to be used for the creation of job opportunities for the people (Olawale, 2017) [3].

(2) Crawling economy and lack of infrastructure- Nigeria is a country with stunted economic growth and distorted economic development. This is due to the inability of Nigerian government to diversify. The country is a mono-economy country relying only on oil as their source of income, leaving other areas such as industrialization in abeyance. This has had great impact on the lives of the citizens in general, as there are no industries to absorb the teaming unemployed youths in the country. As cited in Akande (2014) [18] the national population commission NPC (2013) state that about half of the population is made up of youths, defined as individuals between 15 and 34 years of age. Unfortunately, as the youth population grows, so does the unemployment rate. Another thing is the lack of infrastructural facilities to enhance the life and existence of business or organizations, as mostly power is lacking and thereby making most of the industries run on diesels which in-turn increase their cost of production while affecting profit at the long run. Unemployment is in part caused by an infrastructural deficit (Akande, 2014). Most of the small scale business collapse as they find it difficult to survived in midst of lack of infrastructure, while the bigger factories is being affected due to lack of good roads. (3) Insecurity- insecurity in Nigeria has become one of the major causes of unemployment in Nigeria. The act of kidnapping and the terrorism ravaging Nigerian state has now prompted some of the foreign investors to relocate their companies to other countries where there is peace, as no foreign investors any longer considered Nigeria as a secured place to set up business investment. US department of state, Bureau of consular in their embassy messages in 2019 state that, their citizens should reconsider travel to Nigeria due to crime, terrorism, civil unrest, kidnapping and maritime crime which includes kidnapping, hijackings, boarding's, theft, etc. And that Some areas have increased risk. This is the situation in Nigeria, and the reason for the relocation of some foreign industries to other countries. Foreign investors (industries) such as Unilever and Mobil have relocated their head offices to other countries like Ghana due to the unsecured nature of Nigeria as a result of terrorism ravaging the country (Osewa and Mohammed, 2019) [19]. The decision of the foreign investors not to come invest in Nigeria, and the decision to relocate their investment to other countries are some of the causes of 
unemployment in Nigeria as workers of the relocated companies, for example Dunlop tires are laid off while new foreign industries are not set up in Nigeria.

(4) Over reliance on white collar jobs- lack of entrepreneurial skills and the dependence on white collar jobs by youths is responsible for the surging unemployment rate in Nigeria (Leo, 2013) [20]. Quite a number of Nigerian graduates prefer working in a conducive environment, with well-organized offices that possesses air-conditioner with good office equipment that makes jobs very easy. Non is willing to start up a small scale business or work in an untidy environment such as site for entrepreneurial businesses e.g. Mechanic, carpentry or small printing press place, despite the alarming rate of graduates trooping out of Nigerian universities and polytechnics every year which has led to the high rate of youth unemployment in Nigeria. Graduates are less inclined to engage in business activities that are more labor intensive and skill based, which are prevalent in the informal sector (Sahara Reporters, 2010) [21]. Graduates would prefer to wear a smart suit and tie and sit behind a desk in an air-conditioned office where their take home pay can barely take them home. Career progression is limited and favoritism is life, learning opportunities are illusory (Sahara Reporters, 2010) [21]. This attitude tends to be the general mindset of almost all Nigerian graduates, as non is willing to start from the scratch or become an entrepreneur and small scale business owner. It has gone a long way deepening the rate of unemployment in Nigeria, thereby leading to endemic poverty amongst the people.

(5) Corruption among employed Nigerians on the jobs, and advancement in technology- Reducing of age to get employed, and to remain in office has become normal habit among Nigerians. The older people tend to be the ones found mostly on the jobs while youths are roaming the streets unemployed. This act has become norms among Nigerian older generation, thereby leading to youth's unemployment in Nigeria. The habit of Nigerians senior public office holder securing offices for their children that are yet to graduate from the university is another devilish act that should be addressed by Nigerian government. Another factor is advancement in technology. The world industrial revolution that called for the emergence of technological tools and machines such as computerize machines, computer device and other automotive machines used in the industries is seen as another factors causing unemployment in Nigeria. This robot has been used to interchanged labors that were earlier been used, as only one machine can cover up the job that would have been done by hundreds of laborers within a short period of time, while enhancing productivity and increasing profit. Olawale (2017) [3] argued that technological unemployment is the constant technological changes that have increased mechanization of production which resulted in less demand for man-power and displacement of human labor. What then are the impact of unemployment in Nigeria?.

\section{THE IMPACT OF UNEMPLOYMENT IN NIGERIA :}

The high rate of unemployment in Nigeria has become a national issue of discussion which has affected the country in so many areas. The impact of unemployment has been viewed by this writer from the political impact, economic impact, social impact, security impact and developmental impact. Each of it is addressed below.

(1) Political impact- To a greater extend, the politics of Nigeria has been bastardized by selfish and overzealous politicians who always want to be in position at all cost, as the use of political thugs in snatching ballot boxes and destabilizing of election process has become the order of the day in Nigeria. This act would have been unrealizable if not for the higher rate of unemployment, youth's idleness bedeviling the Nigerian state. Often time, the hungry youths are vital instruments mobilized for selfish political ambitions either as thugs or like (Isayinka, 2019) [5]. Those youths that would have become leaders of tomorrow, and pillars of these nation Nigeria has been made to become area boys and street thugs that have end up been used by overzealous politicians as political thugs. The youths are used as thugs in political campaign, and are manipulated to do dirty deals (Alphonsus, 2019) [22]. Hence ruining the future political advancement of this country Nigeria.

(2) Economic impact- Any nation battling with high rate of unemployment can never grow economically. Even though unemployment has been seen as a world-wide economic problem and has been categorized as one of the serious impediments to social progress (Uniprojects, 2020) [23]. Nigeria is a country where her teaming matured youths greatly depends on parent for survival. Youths that would have contributed their quota to the economic development of the country if were gainfully 
employed. Most of Nigerian unemployed graduates would have become potential investors and employers of labour if they were first employed after leaving the university. To become investors and employers of labour who can contribute to the economic development of one's country, certainly one need a startup capital, and to gather these capitals and the experience need, one need to be employed by another employer, either government or a private organization. It was even argued that not only that the work force will produce manufactured goods or services, or agricultural produce in direct proportion, but also brings in its wages increase, purchasing power which in-turn fuel economic growth (Njoku and Ihugba, 2011 in Oden, 2020 [24]).

(3) Social impact- unemployment in Nigeria has affected the developmental interactions of Nigerians with one another especially at the local communities, as it has led to rural- urban migration. Many youths in the local communities have decided to move to the urban areas in search of jobs which have in turn hampered the development of the rural area. The consequence of unemployment in Nigeria indeed includes increase rural-urban migration, reduction in national output of goods and services and high level of poverty in Nigeria (Olawale, 2017) [3]. Many graduates and or youths that would have been experts in so many fields such as economy, political, security, engineering etc. Has been forced to take up professions in the music, films, dancing and football industries believing that they can survive in those areas easily while quite a number of them are whiling always time without any success in that area, hence ruining their destiny. Many teenagers, girls hawking on the street as a result of unemployment has fall easy prey to rapping as many have been impregnated, hence ruining their destiny.

(4) Security impact- The security impact of unemployment in Nigeria is so devastating that many Nigerian youths have become potential criminals as they have become competent members or collaborators in various emerging armed crimes, such as kidnapping, modernize armed robbery, terrorism, herdsmen syndrome etc. Youth's idleness in Nigeria has now made Nigerian youths fall easy prey while others have personally decided to take up criminal activities for survival as they are being bought over cheaply by many criminal groups to work with them as a member. The rising level of unemployment in the country (Nigeria) can be attributed for the increase in security challenges in the country (Adesina, 2013) [25]. So many Nigerian youths has decided to take up engagement with other none armed crime such as yahoo-yahoo, 419, and drug trafficking, hence increasing the security challenges in Nigeria. Adegoke revealed that there is a significant relationship between unemployment and the security challenges in Nigeria (Adegoke, 2015) [26]. The saying that an idle hand or mind is the devils' workshop.

(5) Johan Gatung in his peace emphasis, it was deduced that conflict is the situation whereby persons thought overpowers or overwhelms his consciousness. That is, a situation where persons devilish thought to engage in evil act such as crime overshadowed his consciousness to realize the consequence and punishment behind such act. When one is unable to think of, or realize the consequences behind a crime due to frustration, then one would see the need to engage in crime. That is the situation in Nigeria as many unemployed youths no longer realize the consequences of crime as a result of frustration and have decided to take up criminal act as a means of survival at all means. This is a great conflict on the nation which would never call for peace in Nigeria except quick response is taking by the government to tackle the increasing rate of unemployment in Nigeria. The writer of this article is also trapped in this unemployment challenges, as he is currently managing his small scale business.

(6) Developmental impact- unemployment in Nigeria has really led to brain drain. Many unemployed graduates, youths and able-bodied youths that would have been use to develop these nation Nigeria had all relocated to other developed countries as they are the ones leading in so many fields such as engineering, medicine, etc. Thereby developing other people's countries, while Nigeria is left undeveloped. The above statement is caused by the high level of corruption in Nigeria. Nigeria is one of the countries in West Africa sub-region whose development has been undermined by the act of corruption https://www.longdom.org>corruption.

7. INVESTING IN SMALL SCALE BUSINESS AND ENTREPRENEURIAL ACTIVITIES: A WAY OUT OF THE UNEMPLOYMENT AND POVERTY RAVAGING NIGERIAN STATE : 
Nigerians has long been ravaged by poverty and penury due to the high rate of unemployment ravaging the country. There is also the need to find out workable solutions to the high rate of unemployment ravaging the country so as to reduce the security challenges caused by citizens' idleness.

Many citizens have imbibed the believe that the only solution and escape route to country engulfed by poverty and high rate of unemployment is to embarked in act of crime (armed and unarmed) as a means of survival. Many citizens have engaged themselves in crime such as drug trafficking, yahoo- yahoo, armed robbery, kidnapping, terrorism and other social vices (Osewa, 2019) [4]. However, this paper is seeing massive investments in entrepreneurial activities and small scale business as a possible way out of the poverty caused by the rising unemployment rate in Nigeria. Due to the current economic downturn in Nigeria, there have been a lot of call and push for entrepreneurship (Olawale, 2017) [3]. The government, organization, different individuals etc. want people to start their own business (Olawale, 2017) [3]. The Company Allied Act of 1990 set out the guild lines for owning a business in Nigeria. Citizens and non-citizens are permitted under the law to own a business in Nigeria. To owned a company of yours. One has to register the company with the corporate Affairs commission (CAC) (www.nigeria-law.org $>$ businessinnigeria) [27].

The constitution of Nigeria allows citizens to own any business except those businesses under the direct interest of the government e.g. Defense, currency power, etc. (Ayaele, 1994) [28]. Nevertheless, citizens of Nigeria should engage in business as it will tackle the issue of unemployment caused by bad governance, enhances Nigeria economy, kill the spirit of over reliance on white collar jobs and tackle insecurity in Nigeria. When citizens engaged in one business or the other, it will kill the idleness of citizens and make citizens not resort to crime as a means of survival. Here, let us discuss the feasibility study of some small scale business organization.

\section{FEASIBILITY STUDY ON SOME SELECTED SMALL SCALE BUSINESSES ENTERPRISE :}

\subsection{INTRODUCTION}

Nigeria is indeed blessed with numerous natural and mineral resources, however, mismanagement, corruption; embezzlement of public fund by bad leadership has become the order of the day. "Nigeria is a nation that is endowed with multifarious and multitudinous resources both human and material. However, due to "gross mismanagement, profligate spending, kleptomania and adverse policies of various governments of Nigeria, these resources have not been optimally utilized" (Osinubi, 2006) [29]. "These resources have not been adequately channeling to profitable investments to bring about maximum economics benefits. Nigeria has been bedeviled with unemployment and poverty" (Osinubi, 2006) [29]. However, "all hope is not lost because of the type of economy we practice in Nigeria, mixed economy. It affords both individual and government the opportunity to participate in the production of goods and services". The idea "entrepreneurship has now become an important program that individuals embark upon. It offers someone the avenue to engage in a business that could serve as a source of income rather than waiting for a job offer from a prestigious firm".

It is expedient for us to understand the concept entrepreneurship before identifying and discussing the aspect of my feasibility study which we have embarked upon. Entrepreneurship is a product of laissezefaire (freedom) or capitalism as propounded by Adam Smith (1776) [30] which permitted free entry of the merchants to the market". J Baptize (1803) [31] described "entrepreneurship as the function that involves the bringing together of the factors of production (land, labour, capital, machine, entrepreneur) with the provision of management and bearing the risk associated with the venture". An individual who carries out entrepreneurship activities is known as an entrepreneur. The word entrepreneur is derived from the word entrepreneurship. Drucker (1983) [32] described "entrepreneur" as any person who coordinates other factors of production, and bears the risk of uncertainty by investing his scarce resources in the business venture". "Entrepreneurial activities are substantially different, depending on the types of business that is involved. The" most fascinating fact about entrepreneurship is starting a business of your own which makes you independent. Entrepreneurship brings growth into the economy of a nation". "In view of this, it is the policy of many governments to develop a culture of entrepreneurial thinking in the minds of her citizenry. This can be done in numbers of ways, by integrating entrepreneurship into the educational system, legislating to encourage entrepreneurship activities among the citizens, creating enabling environment for entrepreneurship activities to thrive", 
etc (Lecture Material on Politics and Entrepreneurship, 2011 [33]). The aspect of our feasibility study which we shall be identifying and discussing are block making industry, car wash center and furniture gallery as an aspect of entrepreneurship.

\subsection{STARTING THE BUSINESS :}

"Before embarking on the business, there are certain factors that must be put into consideration. These factors include, location of the business, capital base of the entrepreneur, size of the business, risk involved, nearness to raw materials and labors and good roads", etc.

"The location of any business is a crucial factor to the success of such a business". For business such as block making business, car wash and furniture gallery to thrive, it must be sited in a place where the entrepreneur can have access to water, motorable road where customers can access easily. Second, the capital base of the entrepreneur is also essential. A business-like block making, car-wash center and furniture gallery requires a huge capital for a start, although depending on the size of the business and business packaging applied. Another thing is the size of the business. The entrepreneur must have a foresight as regards the size of the business, if it will be a large, medium or small scale type of firm. Forth is the risk involved in setting up the business. Business like the above with high risk must duly consider the following. Some of the risks are challenges of competitors, the capital invested in the business, the uncertain possibility of the business thriving or developing within the space and time (spaciotemporal effect), draconian government policies that may affect the business etc. Last, is the risk of getting the business sited in a new site where block making business can thrive, another thing is that some of the blocks may get broken during production and the fact that there is always decrease in sales of blocks during raining season. For car-wash and furniture business, they have to be sited in a densely populated environment where car-wash and furniture business can thrive, as well, nearness to good roads, raw materials, labors and customers. To start with, block production is of two types. They are the machine block production process and manual block production process. Both processes have its own requirements which must be adhered to in order to guarantee the success of the business

\subsection{MACHINE BLOCK PRODUCTION :}

The tools needed for the machine block production process are:

1. Lister Machine $=\# 150.000-\# 200.000$

2. Molding Machine Leg vibration $=\# 300.000$ or Space Vibration $=\# 350.000$

3. Pullet (usually like plank) $=\# 300$ each

4. Sand, sharp sand $=\# 15000$ per load or Gum sand $=\# 12000$ per load

5. cement $=\# 2500$ per bag

6. Drum $(\operatorname{tank})=\# 10,000$ for one

7. Labourers, 1 operator, 1 mixer, 2 carriers. Four (4) individuals are enough to start.

8. Wheel barrow $(1)=\# 10,000$ each

9. Spade $(3)=\# 3000$

10. Shovel (2) $=\# 3,400$

The afore-mentioned tools and laborers' are what are required to start up a machine block production industry. The start-off capital for this business is approximately a minimum of $\# 700.000$ excluding the amount for the land to be purchased or rented. The amount for rentage or purchase depends on the area. A minimum of a plot of land is at least required. The block production industry has an association and anyone who which to set up block making industry must be ready to pay and join the association. The fees depend on the area where the business is set up.

\subsection{A MANUAL BLOCK PRODUCTION}

The tools needed here are:

1. Mould $=\# 15000$

2. Spade $=\# 1000$

3. Shovel $(2)=\# 3,400$

4. Drum (water tank) $=\# 10.000$

5. Wheel barrow $=\# 10,000$

6. Sand, sharp $=\# 15000$ or Gum sand $=\# 12000$ per load

7. Cement $=\# 2,500$ each bag.

8. Laborers. 1 or 2 persons can start the business. 
The above listed tools and number of laborers are what is needed to create a manual block production industry. Anyone who has proposed to embark on this manual block production industry must have at least approximately \#200,000 excluding the outlay required for the land to be purchase or rented. Anyone starting this business need at least a plot of land, and be aware of the association fees.

8.5 FINANCIAL ANALYSIS FOR BLOCK PRODUCTION :

This involves putting every needed labour or capitals to the business so as to create a tangible product. From our idea, the basic idea is block production and before this idea can be transformed into a tangible, marketable and satisfying product. Certain factors are required. Apart from what it takes in starting up the business. These are the required asset (laborers and capital) for the production process. Sand, cement, wages and water (optional). The listed assets would be enumerated in terms of types and price in the table below.

Table 1 : Sand per trip

\begin{tabular}{|l|l|l|l|}
\hline Types & Sharp & Gum & Mixed \\
\hline Amount (\#) & 15000 & 12000 & 15000 \\
\hline
\end{tabular}

Source - field survey (2019)

For the purpose of cost efficiency, the mixed sand would be preferred for production because it contains both sharp and gum sand and for a better block production a mixture of both is needed.

Table 2 : Cement per bag

\begin{tabular}{|l|l|l|}
\hline Types & Dangote & Elephant \\
\hline Amount & 2500 & 2400 \\
\hline
\end{tabular}

Source-field survey(2019)

Table 3 : Wages per cement bag

\begin{tabular}{|l|l|l|l|l|}
\hline Laborers & Operator & Mixer & Carrier 1 & Carrier 2 \\
\hline Wages & 250 & 200 & 150 & 150 \\
\hline
\end{tabular}

Source-field survey (2019)

Concerning the cement and labour to be used, elephant cement would be preferred and four (4) laborers would be sufficient for an effective and efficient start-up.

8.6 COST OF PRODUCTION PER TRIP OF SAND :

Before the cost of production can be determined let's consider the relationship between the assets needed for production and how they can be measured.

A trip of sand and cement can be measure in number of wheel barrows contained. Therefore:

1. A trip of sand $=$ fifty wheel barrows

2. 10 bags of cement to mix fifty wheel barrows

From the above, we can realize that:

Ten bags of cement to mix a trip of sand. Secondly, wages for laborers is measured by the bags of cement used. Therefore: one bag of cement $=\# 750$ wages. Ten bags of cement to mix a trip of sand, wages for mixing ten bags $=7,500$.

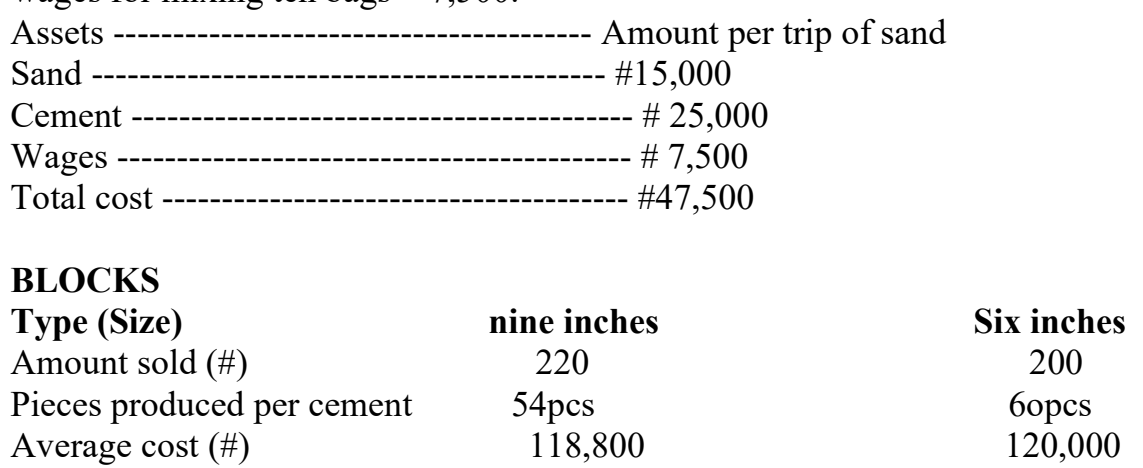

Note - During production, two different size of blocks are usually produced ( 9 inches and 6 inches), and each goes for \#220 and \#200 respectively. A bag of cement in turn determines the numbers of blocks produced over all: for the 9 inches 45 pieces of blocks would be produced and for 6 inches 60 pieces of blocks would be produced using a bag of cement each.

\subsection{PROFIT ACRUE FOR A TRIP OF SAND}


Cost

Production cost

Sales cost

Profit available
9 inches

47,000

118,800

71,800
6 inches

47,000

120,000

73,000

On a normal circumstance the entrepreneur stands to gain an average of $\# 71,800$ for producing 9 inches and $\# 73,000$ for 6 inches from a single trip of sand.

\section{CAR WASH CENTER :}

The equipment's needed for car wash business is analyzed below. However, we have decided not to carry out the financial analysis of what its cost to start the car-wash and furniture gallery business because the prices of the materials needed here differs based on the type or quality of materials chosen to be use, the place where the materials are sold e.g. Lagos price may be different from the price in Ado Ekiti.

1. First is to get a well-positioned land at least a plot

2. Second, is to interlock or floor it depending on choice and capital.

3. Third is drilling of borehole, constructing of scale-folding with a GP tank and pumping machine

4. Fourth, construction of plumbing roofing

5. A powerful generator

6. Car wash pumping machine

7. Steam wash machine (hot and cold water machine)

8. Sand mobbing machine and motor ladder

9. Construction of wooding panel for admin office and customers relaxation center

10. Car wash soaps, hand gloves, rain-boots, water-proof vest and hard brushes.

\section{FURNITURE GALLERY :}

The needed equipment for furniture gallery: (1) construction of an apartment with woods, at least to start with, with the front made of glass to show case furniture's. (2) Painting of the gallery with combine flashy colours with big sign post advert. (3) Potable or 16 inches television set and fans, if possible, an air conditioner to make the gallery more attractive, (4) Front desk table and chairs and customer relaxation chairs. (5) The construction of at least two sets of fanciable beds, upholstery chairs and an office table and chair to be show-case at a start, after which a very tedious marketing strategy follows. The aforementioned tools are what are required to start up a car wash and furniture gallery business. However, in a situation where the entrepreneur is not financially buoyant enough to procure a land. He may decide to rent a piece of land. But it is advisable to buy a land which will be forever yours so as to guarantee permanent stability and off-set future relocation of the business, as the owner of the land may want you to leave haven noticed that the business is thriving, and with the intention to later set up same business.

\section{MARKETING ANALYSIS :}

In this section we considered our market, competition, method of pricing, advertising and selling.

\subsection{OUR MARKET}

The business, block industry can only thrive in developing areas, in rural or sub-urban environs where building construction of any type is in progress. Usually in any market, there are key targets. As to this business, we would focus our target on two key persons in the market, namely: the construction engineer and the owner of the project. Our aim of choosing this people is because they have a deep influence on the project. For a major or big project, a construction engineer would be needed to oversee the completion of the project and we having a good link with this person give us a greater advantage of becoming the block supplier. On the other hand, if the project is minimal, the owners of such project would have an overall say, while we having a cordial relationship with him also boost our chances of producing blocks for him.

\subsection{COMPETITION}


Our ability to stand firm and strongly compete with others in the business would be based on the uniqueness of our service, price, placing and strategy of advert placement, such as internets, radio advert, doorsteps visitation and canvassing etc. The following method would be involved.

Discount Strategy: we shall be involved in two types of discount depending on the type of customer we are dealing with.

(1) Price Discount- Despite the fact that our colour combination, location and attractiveness of the place will its selves call on customers, we shall also give price discount. When dealing with customers, we can beat down price of our product at a start to force ourselves into the market and force out our competitors from market. This would result to cost effectiveness on the customers and higher turn-over and profit efficiency on our side.

(2) Seasonal Discount- Car wash business usually thrives more during dry season. Our initiative is to give our customers more reasons to wash in any season. While the price discount runs through the dry season. Seasonal discount would go for wet season, practice would help reduce the risk of low sales during the rainy seasons, and monopoly of sales at rainy seasons can be achieved. we will also give after sales delivery service in our block industry.

Uniqueness and placing strategy: The quality of the product would remain the same while our method of offering services would be re-branded, as series of moral and ceremonial welcoming and after sale services shall be given to customer e.g. Sales and delivery, etc.

Advert strategy: For a start, we will consider personal contact with drivers at various motor parks, building engineers, organizations and street awareness. These types of advert would incur less cost and at the long run, it will speak for itself. But later, advert placement such as radio and television advert, internet advert etc. Shall be included as these will go a long way in broadening our market.

\subsection{PROVISION FOR/ OR MANAGEMENT RISK}

All forms of risk of the business can be controlled but that which is of more importance is the risk of space and time within which the business will develop to its brake even point. Change in taste and fashion as in the future time when new method of washing cars, molding blocks and new fashion of furniture shall be introduced, and the possibility of more competitors coming into the business. The entrepreneur shall be conscious of the growth of the business on time, at least a year interval to the profit realization, and work tirelessly to change along with trend (taste and fashion), and apply more market strategies to go ahead of his competitors. As the business grows so shall more business strategies be introduced.

\subsection{CONSTRAIN OF THE BUSINES}

There are certain factors that pose threat to this kind of businesses. These factors are:

(1) Rain: During raining season, business tend to be very low for a car wash business, since rainfall is a natural occurrence, car-wash business don't usually get boomed at this season. (2). Time consciousness: workers who come late to work hinders the success of the business since they will not be able to serve as expected, as it will cost customers waiting for a very long time, and also effect the profit of the business. (3). Bolt and Boris: The listed machine used in this type of business can as well develop a fault thereby hindering the work on ground. If the belt and Boris attached to the machine becomes faulty, invariably the work will be hampered.

During the investigation of the feasibility study. It was discovered that the largess of the money put into the business could contribute greatly to the business and increment in productivity and profit. The level of the risk taken determines the rate of its profit. A real entrepreneur is one who takes high level of risk. Once the business has developed to certain stages, then the idea of expansion, in terms of the introduction of new business to it, such as eatery, dry cleaning and laundry service, football viewing center etc. and the idea of branch opening, all in the future.

In a nutshell, from our findings, based on the feasibility study carried out on the three business (block making, car-wash center and furniture gallery), we can say emphatically that the three businesses are a very lucrative business venture provided the needed tools are available with a very competent manager to run the business. A successful entrepreneur is one who takes high level of risk. The level of risk taken determines the possibility of higher success in the business. These types of business are one that fetches its profit within short period as opposed to other business thought of such as school or extra- moral classes, transportation that is with a very high risk of uncertainty etc. That can tie down capital, and with lack of certainty of continuation. Let us not forget the fact that, for any business to 
thrive in any environment, the government must have provided all the facilities needed to enhance the success of such business.

\section{THE NEED FOR NIGERIAN GOVERNMENT QUIKER INTERVENTION IN THE CREATION, GROWTH AND DEVELOPMENT OF SMALL SCALE AND ENTREPRENEURIAL SKILL DEVELOPMENT IN NIGERIAL :}

Years back, there have been emphasis by the government, private organizations and individuals, encouraging citizens of Nigeria to cripple the idea of searching for white collar jobs, this is due to the backward economic condition, failure of the government in taking and rendering her constitutional responsibility of creating jobs opportunities for its citizens. It was reported by the Daily Trust February, 2020 through the Minister of labour and employment, Chris Ngige that federal government of Nigeria has advised unemployed graduates in the country to stop seeking white collar jobs, asking them to look elsewhere for sustainable alternatives (Usman, S.U, 2020) [34]. Idea of jobs creation that has been eroded by corruption and embezzlement of public funds meant for job creation, societal development and hence increasing unemployment rate in the country. Citizens of Nigeria have been advice to turn to the idea of establishing small scale businesses and or the adoption of entrepreneurial skill development which is fast seen as the only escape route from the unemployment ravaging Nigerian state.

Nevertheless, it is a factual that small scales businesses and entrepreneurship thrives only in an environment with the necessary facilities that can enhance its survival and makes business thrives. Helping small businesses start and thrive is a win-win situation for the government (Edmund and Seidel, 2019) [14]. The start-up capital to establish the business is also necessary. For example, the government in US through her agencies provide loans guarantees to small business and encourage local banks to work with start-up or established companies that want to expand (up cit). Environment like Nigeria that is lacking infrastructures, social amenities do not guarantee the survival of any business investment. This is the more reason for government quick intervention in small scale business establishment and development. However, it is also germane to say that the government has been doing their best, but really, the government still needs to do more, I mean doing the best of their best. Government intervention in area of infrastructure and social amenities development, especially power is needed to enhance the thriving and survival of small-scale businesses and entrepreneurship development in Nigeria. Infrastructure such as good roads, rail lines, power, air-port and sea port is needed for the free movement of raw- materials and finished goods to the market. Government should help improve the infrastructure needed for business to succeed, which include building and maintenance of road, bridges, rail-line, air-ports, sea ports, energy transmission line and telecommunication system (Edmunds and Seidel, 2019) [14].

Taxation is another area that the government needs to work on. Double taxing small scale business owner, i mean imposing federal government, state government and local government tax on small business that is just set up or just growing up can affect the business. Tax related issues like multiple taxations and enormous tax burdens such as double tax assessment on the profit of the business and income of the owner are among the factors responsible for the untimely business close-ups (Iproject, 2020) (35). Placing huge taxes on small scale businesses may also affect the business, thereby leading to the collapse of the business. Some small business is just too small to be evilly tax as they are just been set up by some helpless Nigerian graduates with very small capital, if such business is double tax it will surely liquidate within short period. When a single amount of money is taxed more than once, often by two or more different authorities in a way that may be unfair or illegal, it may affect the business (Bateman, 2007) [36].

Another thing is that Nigerian government is needed to provide education and training programs to citizens. The governments have been doing these through the various local government skills acquisition programs that involves training and grants, even though most of the beneficiaries happens to be the families and friends of the politicians of the party in power. However, there is the need for the creation of training schools in every local government of the country and the giving of loans and grant to genuine citizens after training to stat up a small scale business of their own. The universities, secondary and primary education programs needed to be revamped to include intensive skills acquisition programs and loaning to start up a self-business. Embed creativity and innovation training 
into each course, subject taught in the class room and make creativity and innovation just as important as the other core subject (Philmckinney, 2010) [37].

Loan guarantee programs are another area that the government effort is needed. Although there have being various programs by the government through central bank and world bank in loaning and giving grant to the citizens of Nigeria in enhancing growth of small scale businesses in Nigeria, government alignment with foreign organizations owned by the Chines, Indians and Americans have also been realized in the past, corporations that have called for the investment of businesses, training of citizens, and granting of loans to citizens of Nigeria especially in areas of agriculture. Nevertheless, it is important to note that the key problem facing most small and medium industries is lack of finance whether for the establishment of new industries or to carry out expansion plan (Oden, 2019) [38]. However, government intensive effort is needed in terms of given loans, grant to citizens in a monitored manner, in order to ensure that the loans given get to the right beneficiaries because studies have highlighted the limited access to financial resources available to smaller industries compared to larger organizations and the consequences for their growth and development (Udechukwu, 2003 in Oden, 2019 [38]).

Company such as Leventis foundation, UAC, imperial college of business and development studies, Emure Ekiti ibay woman fadama farmers, Marvico farms LTD, Psaltry international LTD, etc. Have been training on agriculture and giving loan to citizens. Research in the areas of small businesses, is very important as it will help enhance the growth and development of small scale business in Nigeria. Nigerian government is needed to collaborate with some private and government research institute such as National Institute of Social and Economic research (NISER) and the universities by financing them to carry out research on the growth and development of small scale business and entrepreneurship development in Nigeria. The federal government must provide grants to academic institutions working to develop new technologies that will benefit industries with the caveat that the institutions will share the technologies with industries (Edmund and Seidel, 2019) [14].

Economic development programs are another area where the government is needed ensuring that import and export duties is reduced, and that very limited taxes are levelled on small scale business is very important. Some government programs help businesses start, grow and relocate to specific areas (Edmund and Seidel, 2019) [14]. "In some ways, local, state and central governments compete with each other for jobs. They do this by offering start up incentives and taking steps to create a "businessfriendly" which includes tax credits, workers training, free land, zoning charges, low-interest loans, infrastructure improvements and help with fast-tracking licensing and permitting"' (op cit). Nigerian government also need to revamp the polytechnic system to include teaching of the technical skills so as to meet up its motive of establishment, because polytechnic has now moved from running practical technical courses to running theoretical courses like the university. We have so far been preaching the adoption of the habit of investing in entrepreneurial activities as a way of tackling the high rate of unemployment in Nigeria. However, who is an entrepreneur?

\subsection{WHO IS AN ENTREPRENEUR?}

In setting up small scale business, there is an individual who must have invested his or her money and bears the risk of loss, coordinates and integrate other factors of production in such a way that profit is assured as resources are efficiently and judiciously utilized. That individual is called the entrepreneur. However, Hayes (2019) [39] argued that an entrepreneur is an individual who creates a new business, bearing the risks and enjoying most of the rewards. He further submits that an entrepreneur is commonly seen as an innovator, a source of new ideas, goods, services, and business or procedures. Kumar (2017)[40] argued that an entrepreneur is a person who organizes and operate a business or businesses, taking on greater than normal financial risks in order to do so. The main point articulated in both definitions is the person, who invests his capital, bearing the risk, organizes and operates the business. He is seen as an innovator and inventor. That is to say he is the major factor, a human factor that organizes other factors such as land, labour, capital and machines, investing his capital in order to make more capital. Entrepreneur is the brain box of the business. By inventing and innovating, he is adding significantly to the economy of the country. As an employer of labour, he is reducing unemployment rate in the country.

\subsection{FUNCTIONS OF AN ENTREPRENEUR}


Entrepreneur as the brain box of the business, and as the main risk bearer, he has some managerial functions expected of him. These functions are same as those functions perform by a manager in a business organization, but may slightly differs in that they are myopic when compared to that of a manager in a big firm. Startupnock (2019) [41] listed and explained some of the main functions of an entrepreneur as thus:

Taking initiative- Taking initiative is all about taking charge and responsibility. It involves innovation, risk-taking, planning and managing resources to achieve the desired objective.

Risk bearing- As an entrepreneur, you have to be extremely courageous to bear risks in business rather than to avoid it. A new business always involve risk because one invests money to get profit shortly in the mix of competition with the bigger businesses, shortage of raw materials, change in customer preferences, etc.

Bring innovation- The purpose of innovation is to constantly grow an organization through new products, more productive techniques, efficient processes and flexible business models. Most importantly innovation helps to create a monopoly in the market by providing a competitive advantage. Decision making- Being able to make quick decisions is one of the most important traits of a business entrepreneur. The purpose of making a decision is to bring result to your business

Organization building- Brood accomplishment in business is accomplished by actualizing a long haul and taught an approach that advances customer centricity, development and talent propensity. Consequently, it's an entrepreneur job to introduce innovative products or services in the market, gain traction and manage resources, consistently deliver great customer value, explore opportunities for business expansion and build a culture of continuous innovation.

Entrepreneur also takes other managerial functions such as the ones developed by Gullic and Urwick in their acronyms POSDCORB, which implies planning, organizing, staffing, directing, coordinating, reporting and budgeting. Management in all spheres of lives involves the above managerial functions. At this juncture, let us looked at other ways through which the menace of unemployment can be tackled in Nigeria.

\section{RECOMMENDATIONS :}

\section{(1) OTHER WAYS THROUGH WHICH UNEMPLOYMENT CAN BE TACKLED IN NIGERIA}

Apart from the idea of financially and educationally encouraging the unemployed citizens of Nigeria to adopt the idea of investing in, and starting a small scale business and entrepreneurial activities as a way out of the menace of unemployment in Nigeria, there are other ways through which unemployment can be tackle in Nigeria as discussed below :

Nigerian government should do business- creating jobs opportunities for citizens is one of the functions of every government, if at a point in time the government fails to take up this function, then such government is seen to have failed in its responsibility of guaranteeing welfare to her citizenry through jobs creation. Other ways, through which Nigerian government can create jobs apart from ministerial employments, is that, Nigerian government should also do business by incorporating in Nigeria constitution at the National Assembly the reasons for Nigerian government to do businesses, and also make the provisions in the National budget, the capital to invest in small, medium and large business organization. Advanced and more civilized countries government like the USA, Britain, Germany etc., all do business. Nigerian collapsed companies e.g. Ajaokuta rolling steel industries, Nkalagu cement industries etc., should also be redeemed, as this will call for the emergence of new jobs opportunities in Nigeria.

Building the environment to be conducive for business operations- a country economy or environment that is robust and conducive for business operation will certainly create atmosphere that will call for foreign investors to invest in such country. Nigeria government needs to do more in terms of effort in ensuring that the economy and environment is robust, with good social amenities, especially power, good roads, railways etc. that can enhance business operations and called for the trooping in of foreign and local investors, as Nigeria is the largest market for goods and services in Africa.

Tackling the insecurity situations in Nigeria- it is expedient to say that the security challenges faced in Nigeria at presence has had greater impact on the economy of Nigeria as foreign investors could not come into Nigeria and invest, while others that are earlier existing e.g. Mobil, Unilever etc. has now 
relocated their head offices to other countries like Ghana. The local investors too could not operate as expected as they are full of fears, especially those investors in the Northeastern part of Nigeria, and that was while sometimes in the past, the Nigerian-American Ambassador once advice American citizens not to come to Nigeria, because Nigeria is not peaceful as Nigerians are battling with insecurity. Certainly, if security is restored in Nigeria, then foreign investors and local ones can invest, hence jobs opportunities in Nigeria.

Enacting laws at the National Assembly, laws that can tackle and punish any public and private organization workers (civil servants and private organizations employees) who indulged in the act of reducing age by altering their documents in order to remain in office for longer than normal, even at old age. The idea by principal civil servants in retaining positions for their families that are still in the universities, to be occupied in the nearest future when they graduate, should also be tackled. Politicians are not innocent in these awkward ideas too. If all of the above recommendations are addressed, unemployment in Nigeria will surely gradually become a thing of the past.

\section{CONCLUSION :}

The rate of unemployment in Nigeria is indeed very high, as the issue of unemployment in Nigeria has now become a daily discussion. The alarming rate of unemployment is indeed dangerous to the health and development of this great nation Nigeria, and if a prompt and proactive measure is not taking, it may lead to greater security challenges. This article has recommended that the government and Nigerians should adopt the idea of small scale business development and entrepreneurial activities as the route to escape from the challenges of unemployment ravaging Nigeria at present.

\section{REFERENCES}

[1] Nwadike, O. Bundu (2013). Nigeria: Worth Dying For. Afronet Publications. Nigeria.

[2] Eke, D. Okwuchi (2001). Perspectives on a stable democracy for Nigeria. Lord Onny International Abia State, Nigeria

[3] Olawale, Johnson (2017). Roles of entrepreneurship in economic development of Nigeria. Retrieved from https://www.legit.ng>asklegit (Accessed 27 $7^{\text {th }}$ Nov, 2019)

[4] Osewa, O.S (2019). Terrorism in Nigeria: Causes, consequences and panacea. International journal of legal studies 2(6) December pp 341-366

[5] lsayinka Stephen (2019). Confronting Nigeria's uneployment crisis. Retrieved from https://punchng.com.confronting-Nigeria (Accessed 16th March, 2020)

[6]Adejimola, S. Amuseghan (2009). Course material for Business investment and management. Centre for entrepreneurial development, Adekunle Ajasin University, Ondo State Nigeria.

[7] Ben McClure (2020). Modern portfolio theory: Why still hip. Investopedia. Retrieved from https://www.investopedia.com>modernportfolio. (Accessed 4th March, 2020)

[8] Espanol, F (2019). Governance. Retrieved from www.ibe.unesco.org $>$ technicalnotes $>c$ (Accessed $20^{\text {th }}$ Nov, 2019)

[9] Barma N.H (2019). Failed State: Government. Retrieved from https://www.britannica.com>topic $>$ failed (Accessed 19th November, 2019)

[10] Global Policy Forum (2013). Failed State. Retrieved from https://www.globalpolicy.org $>$ failedstates (Accessed 19 ${ }^{\text {th }}$ Nov, 2019)

[11] Amadeo, Kimberly (2019). Unemployment Definition, how it's used, causes impact. Retrieved from https://www.thebalance.com>what-is-unemployment (Accessed $20^{\text {th }}$ Nov, 2019)

[12] Chappelow, Jim (2019). Economic>microeconomic: unemployment. Retrieved from https://www.investopedia.com>terms (Accessed $20^{\text {th }}$ Nov, 2019)

[13] Pettinger, Tejuan (2019). Definition of employment. Retrieved from https://www.economichelp.org $>$ blog (Accessed 20 $0^{\text {th }}$ Nov, 2019). 
[14] Edmunds, S.A and Seidel, M (2019). Role of government in promoting small business. Retrieved from https://smallbusiness, chrom.com $>$ role-go (Accessed $6^{\text {th }}$ Dec, 2019)

[15] Edmunds, S.A and Seidel, M (2019). Role of government in promoting small business. Retrieved from https://smallbusiness, chrom.com $>$ role-go (Accessed $6^{\text {th }}$ Dec, 2019)

[16] Olufisayo, O (2010). what is entrepreneurship. Retrieved from https://www.entrepreneurshipsecrete.com $>\ldots$ (Accessed $22^{\text {nd }}$ Nov, 2019)

[17] Ferriera, M.N (2019). What is entrepreneurship, entrepreneur definition and meaning. Retrieved from https://ng.oberlo.com>blog $>$ what-is-en.. (Accessed $22^{\text {nd }}$ Nov, 2019)

[18] Akande, Tunji (2014). Youth unemployment in Nigeria: A situation analysis. Retrieved from https://www.brookings.edu $>2014 / 09 / 23$ (Accessed $4^{\text {th }}$ Dec, 2019)

[19] Osewa, O.S and Mohammed, N.T (2019). Terrorism and human displacement: An impact assessment of Adamawa State internally displaced persons hosted in Durumi IDP camp Abuja. International journal of legal studies, issue 2(6) December, pp 263-299

[20] Leo, Ruby (2013). Nigerian: Unemployment high, due to reliance on white collar jobs. Retrieved from https://allafrica.com>stories. (Accessed $5^{\text {th }}$ Dec, 2019)

[21] Sahara Reporters (2010). White collar jobs and unemployment in Nigeria. Retrieved from www.saharareporters.com $>2010 / 06 / 30>$ white.. (Accessed $5^{\text {th }}$ Dec, 2019)

[22] Alphonsus, E. Ezeoke (2020). Dying Education: Necessary reformation, the Nigerian case. Retrieved from https://books-google.com>books (Accessed $16^{\text {th }}$ march, 2020)

[23] Uniprojects (2020). The impact of unemployment on Nigerian economy. Retrieved from https://uniprojects.net>project-materials (Accessed 17 $7^{\text {th }}$ march, 2020).

[24] Oden, Chrisantus (2020). Effect of unemployment in Nigeria economy. Retrieved from https://nairaprojects.com>projects (Accessed $17^{\text {th }}$ march, 2020)

[25] Adesina, O.S (2013). Unemployment and security challenges in Nigeria. Retrieved from https://www.eldis.org $>$ document (Accessed $21^{\text {st }}$ march, 2020)

[26] Adegoke, Niyi (2015). Youths unemployment and security challenges in Nigeria. Retrieved from https://www.ajouronline.com>view (Accessed $20^{\text {th }}$ march, 2020)

[27] www.Nigeria-law.org>businessinnigeria (Accessed 20th February, 2020)

[28] Ayaele, J.U (1994) Comprehensive Government, Johnson Publisher LTD, Surulere, Lagos.

[29] Osinubi, S. Tokunbo (2006). An Economic analysis of Growth, Unemployment and Poverty in Nigeria. The IJP Journal of Applied Economic IJP Publication, vol 0(1) December pages 53-66

[30] Adam Smith (1774). The wealth of Nation. Investopedia. Retrieved from https://www.investopedia.com>updates (Accessed 4th January,2020)

[31] Baptize, J (1803). Treatise on political Economy. Retrieved from https://www.investopedia.com>terms $>\mathrm{j}$ (Accessed 14th March, 2020)

[32] Drucker, F. Peter (1983). Innovation and Entrepreneurship. Retrieved from https://www.jstor.org $>$ stable (Accessed $14^{\text {th }}$ March, 2020)

[33] Lecture Material on politics and Entrepreneurship, (2011). Department of political science, Adekunle Ajasin University, Akungba Akoko, Ondo State,Nigeria

[34] Usman, S.U (2020). Nigeria: Don't Rely On Us for jobs, Gov’t Tells Unemployed Graduates. Retrieved from https://allafrica.com>stories (Accessed $23^{\text {rd }}$ March, 2020).

[35] Iproject (2020) The impact of multiple taxation on small and medium scale business. Retrieved from https://iproject.com.ng>entrepreneurship (Accessed $25^{\text {th }}$ March, 2020) 
[36] Bateman, A (2007). Globalization of production and the competitiveness of small and medium size Enterprises in Asia and the Pacific: Trends and Prospects. Publication of United Nations Economic and Social Commission for Asia and the Pacific (ESCAP), Studies in Trade and Investment Series.

[37] Philmckinney (2010). What is the role of government to encourage small Business innovation? Retrieved from https://philimckinney.com>role-of-government (Accessed 6th December, 2020)

[38] Oden, Chrisantus (2019). The role of government in the growth of small and medium industries, A project work. Retrieved from https://www.projecttopics.org $>$ role-gove (Accessed $6^{\text {th }}$ Dec, 2019)

[39] Hayes, Adam (2019). Entrepreneur. Retrieved from https://www.investopedia.com>terms $>\mathrm{e}$ (Accessed $29^{\text {th }}$ Nov, 2019)

[40] Kumar, Braveen (2017). What exactly is an entrepreneur and how do you become one today. Retrieved from https://www.shopify.com>blog $>11704$ (Accessed 29th November, 2019)

[41] Startupknock (2019). Top 6 functions of an entrepreneur. Retrieved from https://startup.knockcom $>$ functions-of-a. (Accessed $27^{\text {th }}$ Nov, 2019). 